\title{
IFRS Introduction And Its Effect On Listed Companies In Spain
}

\author{
Jordi Perramon \\ Universitat Pompeu Fabra, Barcelona \\ Oriol Amat \\ Universitat Pompeu Fabra, Barcelona
}

\begin{abstract}
From the beginning of January 2005 publicly traded companies in the European Union have to comply with the International Financial Reporting Standards (IFRS) for their consolidated accounts, as required by 1606/2002 European Commission Regulation. It had been suggested that the new accounting rules will facilitate not only the process of international harmonization of financial statements, but also efficient performance of financial markets and capital flows worldwide. This study analyzes the first results of IFRS implementation by Spanish non-financial listed companies.
\end{abstract}

Keywords: IFRS, IAS, Accounting harmonization

JEL Classification: M41, N24 


\section{BACKGROUND}

From the beginning of 2005 about 7500 companies from the European Union, Iceland, Lichtenstein and Norway have to comply with the International Financial Reporting Standards (IFRS) when reporting their consolidated financial statements, as publicly listed companies subject to Regulation 1606/2002 of the European Union. These accounting rules have been prepared by the International Accounting Standards Board (IASB), which is a private and independent body, i.e. not established from and within a public institution. The European Committee has the right to accept the rules issued by the IASB with expert advice from the ARC (Accounting Regulatory Committee) and the EFRAG (European Financial Reporting Advisory Group).

The objective of this study is to analyze the preliminary impact of IFRS implementation on the Income Statements of the non-financial companies in IBEX 35. For this purpose information from interim reports of the Spanish companies in the index has been collected with a special focus on the reconciliations between the IFRS and PGC (i.e. General Accounting Chart, Plan General de Contabilidad). This data allowed us to observe which are the international accounting standards with a significant impact on the financial results of the selected companies. The reconciliations also revealed the gross impact on the net profit.

\section{PRIOR LITERATURE AND FINDINGS}

\subsection{Harmonization: Definition, Measurement and Limits}

Accounting harmonization is a process (e.g. van der Tas, 1988; Tay and Parker, 1990; Nobes, 1991), which is essential for improving international comparability of financial statements. Choi and Mueller (1984) explained this comparability with "a single 
standard or rule" applied "to all (similar) situations". Nobes (1991) suggested that this comparability of accounting practices is due to the bounds set to their "degree of variation". Tay and Parker (1990) emphasized only that this is a process of "moving away from total diversity of practice" (p. 73).

Scholars in the field suggested different formal definitions of harmonization. Nevertheless, there is more or less a consensus about its broad meaning: it is a process which increases comparability in financial statements in different dimensions, i.e. across time and national boundaries.

A difference between harmonization and harmony exists, the later being a state, not a process, where companies are clustered "around one or a few of the available methods" (e.g. Tay and Parker, 1990: 73; van der Tas, 1992). However, competing explanations about the difference between 'harmonization' and 'standardization' have been proposed. There is also no agreement about how to classify and measure the process of harmonization (Tay and Parker, 1990, 1992; van der Tas, 1992). The alternative approaches are summarized below.

Gray (1980) believed that the difference between harmonization and standardization comes from the driving forces in the process. He suggested that harmonization is a process, which international organizations, such as the United Nations (UN), the European Union (EU) and the Organisation for Economic Cooperation and Development (OECD), direct with their regulatory policy. The standardization process, in contrast, is observable in accounting practice, i.e. in the measurement and disclosure choices of the managers. Nobes (1991) suggested that, even if there is a difference between harmonization and standardization, it is very difficult in practice to distinguish which process prevails. Formally, harmonization increases the comparability of financial statements, while standardization imposes more rigid and 
narrow accounting rules. Tay and Parker (1990) defined standardization as a process of movement towards uniformity, i.e. "clustering associated with harmony and reduction in the number of available methods" (p. 73). In a later publication, the authors (1992) also proposed that harmonization is associated with regulation applying to all companies, legal regulation and/or regulation containing precise definition. In contrast, standardization refers to regulation affecting only a subset of companies, professional regulation and regulation containing discretionary definitions (p. 218). Van der Tas (1992) suggested in his comments on Tay and Parker (1990) that instead of a distinction between harmonization and standardization, it would be more relevant to debate the different levels of details at which to measure the degree of harmony.

Alternative classifications and measures of harmonization have been suggested as well. The majority of research studies in the early 1980s had not computed a single and objective measure of harmonization (e.g. Evans and Taylor, 1982). Their reliance primarily on descriptive statistics and researcher's interpretations has been a reason for them not to be accepted widely in the accounting community. Van der Tas (1988) suggested a single measure quantifying degrees of harmonization, together with a new classification of harmonization. He emphasized that regulatory standards are not means of achieving the harmonization of financial reports, since they are also objects of harmonization. The harmonization of standards differs from harmonization of financial reports, which has been introduced in his classification as formal versus material harmonization. As an example, he referred to material harmonization, which can take place without being initiated by standard setters (spontaneous harmonization). Van der Tas (1988) suggested that a company decides whether to translate a specific event in its financial report, i.e. financial disclosure decisions, and which accounting methods to apply in accounting for that event, i.e. a choice among alternative, regulatory allowed, accounting methods. When the extent of financial disclosure does 
not differ much at industry, country and/or international level, a process of disclosure harmonization can be observed. In contrast, if the relative frequencies of the alternative accounting methods applied are similar, for instance, in two countries, then measurement harmonization is in process. Van der Tas (1988) devised two variants of the Herfindahl concentration index based on relative frequencies to measure material measurement: i) national harmonization when a company provides information for several alternative methods of a particular accounting practice ( $C$ index) and ii) international harmonization (I index).

Tay and Parker (1990) analyzed six studies dealing with the measurement of international harmonization and commented on difficulties applying alternative operational definitions of harmony and study designs. They drew a distinction between material (de facto) and formal (de jure) harmonization. The former refers to harmony or uniformity of accounting regulations, which may be contained in the law and/or professional accounting standards, while the latter measures actual practices of companies. In a latter publication (1992) they emphasized that the measurement of de jure harmonization does not appear to be a useful topic, if the ultimate concern of harmonization is to increase the comparability of financial reporting. Research about de facto harmony in changing the regulatory environment, however, helps to indicate the closeness of the link between de jure and de facto harmonization. Tay and Parker (1990) suggested an alternative measure of harmonization, which focuses on actual reporting practices assessed from annual accounts. Data on the proportion of companies using different accounting methods can be obtained and harmony could be quantified using a concentration index, which describes the entire distribution, not just a proportion of it.

Tay and Parker (1990) discussed the drawbacks of using different measure of harmonization in the accounting field. The major limits come from sample selection, 
sources of data and statistical methods applied. Nobes (1981) emphasizes that there are many methodological difficulties when measuring harmonization with survey data, the main being appropriateness and the validity of data collected. Particular examples from the UK were provided (Nobes, 1981). Tay and Parker (1990) further commented that causality is problematic in these accounting studies. While it may be possible to measure the degree of harmony, it is difficult to distinguish trend movements from random movements (p.84). In addition, it is easier to show the impact of legal regulations on the use of accounting methods and/or disclosure of particular information, since this compliance is regulatory, i.e. compulsory. The harmonization measurement does not account fully for voluntary compliance with professional regulation or other market-driven accounting practices. They criticized the concentration H-index, hence van der Tas's I and C indexes (1988), for not providing significant tests (a problem resolved later with the contribution of Taplin in 2003). Van der Tas (1992), however, commented in a response publication that Tay and Parker (1990) did not illustrate their method, since it is rather complicated and without a solution to other indexes' drawbacks.

Several authors introduce further improvements to the I and C indexes, for example the global concentration index of Garcia Benau (1995) and the comparability index by Archer et al. (1995). Laínez Gadea et al. (1996) concentrate on analyzing the discrepancies among the information requirements imposed by the stock exchanges of 13 countries. Last, but not least, Cañibano and Mora (2000) proposed a bootstrapping test of the $C$ index as a way of measuring the significance of the change in its value.

The study of Pascual et al. (2002) proved that the IASB needed to continue working towards greater formal harmonization.

\subsection{Costs and Benefits of Accounting Harmonization}




\subsubsection{Accounting harmonization and international investors}

Disclosure issues are important from the vantage point of investors and companies. Apparent differences between financial measures of the risk and return characteristics of enterprises in two countries could be due as much to differences in accounting rules as to real differences in the attributes being measured. However, opposite views and contradictory findings have been made public about possible benefits coming from accounting harmonization on the financial market.

Many scholars agree that, in the context of international capital markets, lack of comparable disclosure can hinder the decisions of investors. Because of the need for compatibility of financial accounts prepared under different national GAAPs, stock exchanges limit the GAAP choice, as a result, providing more grounds for financial comparison at international level. Global accounting firms also argued that a common accounting and financial reporting framework is needed, in particular for investors and other users to compare investment opportunities and for a company to benchmark itself against competitors (e.g. GAAP, 2001). However, a large body of literature also suggested that it is not necessary to be regulatory required, since managers disclose voluntary information and financial analysts are able to distinguish credible from noncredible information content (e.g. Baginski et al., 2004). Some authors also concluded that a country's need to access capital markets may increase the trend towards harmonization and country compliance, i.e. the financial market requires more comparable information (e.g. Taplin et al., 2002).

Many scholars, however, suggested that the benefits for the financial information users are not as obvious. Choi and Levich (1991) emphasized that accounting differences that lead to differential cash flows will clearly affect firm valuation. In contrast, accounting differences that change internally reported values may or may not affect investors' estimates, depending upon whether they can perceive the nature of that 
accounting difference. Their survey results did not allow one to rule out the possibility that international accounting diversity is a barrier that may affect the pricing of securities and the composition of international portfolios. Choi and Levich (1991) concluded that, although, for many investors accounting differences are an important factor affecting their market decisions, they feel in possession of a mechanism to cope with this diversity. Leuz (2003) also examined the value relevance of accounting numbers with a study of the New Market in Germany. He concluded that neither the trading spreads nor the trading volumes were significantly different for the companies that choose the IAS or U.S. GAAP. Leuz (2003) suggested that it might be that, despite the differences in the standards, institutional factors and market forces drive compatibility of financial results prepared under different GAAPs. Ball et al. (2003) concluded after their empirical test that it is incomplete and misleading to classify countries based on their formal accounting standards or standard-setting institutions, since the institutional factors, such as institutional influences on preparers' actual financial reporting incentives, matter in accounting decisions.

\subsubsection{Accounting harmonization and multinational companies (MNCs)}

Several authors have suggested that diversity in accounting rules and practices creates difficulties for the efficient operation of multinational companies. As a result, they proposed other benefits, such as cost reduction and more efficient management, coming from accounting harmonization. Mason (1978) identified a couple of possible benefits for the multinational companies if harmony among accounting systems exists worldwide. Firstly, the costs of preparing consolidated financial statements would be

lower for the companies' headquarters. And, secondly, global accounting harmonization would allow an integration of the internal reporting systems and would 
facilitate the common human management policy of the company. Many consulting companies repeat Mason's suggestions in relation to the IFRS adoption in Europe, stating that MNCs will appreciate the introduction of a common business language that will reduce GAAP reconciliation effort and promote mobility of accounting and other managerial staff. Cecchini (1988) quantified benefits of a single European market in his study, including those for MNCs. He estimated that, as a result of reporting and taxation diversity in different European countries, MNCs in Europe have higher administrative costs, i.e. in his estimates between $10 \%$ and $30 \%$ of the costs of MNCs' department units involved in the international compatibility process.

\subsubsection{Accounting harmonization: standards evolution and spread}

A lot of publications focus on the development of international accounting standards worldwide. Some authors distinguish different spheres of influence, while others look at the players in that dominance game (e.g. the research on the "transfer agents" like accounting professors, international accounting firms). Competing views have been expressed about whether the harmonization process assists more than obstructs proper functioning of national accounting systems. For some scholars, countries with less developed accounting standards benefit from the application of already established and well operating financial rules. However, for other authors reporting incentives depend not on regulatory standards but rather on reporting incentives, factors determined by the institutional environment.

Researchers finding benefits from the accounting harmonization underlined that the existence of high quality and well operating accounting standards facilitates the regulatory process of less developed counties (e.g. Baccouche, 1969; Mason, 1978). Mason (1978), for instance, observed that the accounting profession in developing countries is not as advanced as in developed countries, which impedes the introduction 
and implementation of high-quality accounting standards. He noticed that these countries can benefit from the international standards within the process of accounting harmonization. Beresford (1990) provided an example how the transfer of knowledge and regulation in the accounting field works. He confirmed that the Financial Accounting Standards Board (FASB) advised the Hungarian government in the process of accounting standards introduction.

Other scholars emphasized that countries differ a lot in their legal and finance systems, hence they differ in reporting principles and practices. This might mean that there would be unnecessary costs for market participants from the compulsory application of common standards. Corporate governance structures in code-law countries are different from those in common-law countries. Code-law systems typically assume that firms transact with stakeholders, who are represented in the governance structure and, thus, privately informed about relevant events. As a result, the introduction of regulatory requirements useful for U.K (i.e. common-law countries) for instance, would be not only unnecessary, but also costly for German companies (i.e. code-law countries). In addition, as Ball et al. (2003) confirmed with a sample of East Asian countries, institutional factors rather than regulatory requirements matter. In other words, the simple introduction of accounting standards of one country does not make them work in a different one, as managers have different information disclosure incentives. Several authors also questioned the necessity of accounting harmonization. For instance, Rivera (1990) observed that the evolution of financial markets and the standards comparability was possible even before the initiation of the accounting harmonization process.

\subsubsection{Accounting harmonization in a political context}


There are mixed assessments of accounting harmonization, i.e. its costs and benefits, when political arguments are involved as well. Some authors emphasized that the introduction of IRFS in Europe is beneficial, as it might be seen as an alternative to the U.S. dominance. For instance, Mason (1978) observed that if international accounting standards were not developed, the U.S. GAAP would fill the need for common accounting rules. He found support for his statement in the outstanding financial performance of the American MNCs, the high-quality of the U.S. accounting system, the quality of the U.S. accounting literature and professional journals in the accounting field and the strong American academic accounting community. Hapwood et al. (1990) confirmed Mason's arguments. However, they stated that the larger volume of international trade and capital flows, which have increased in the last decade, require a comprehensive and internationally accepted accounting system. The authors emphasized that in case accounting harmonization does not take place, one of the existing accounting systems will prevail over the others. Hapwood et al. (1990) believed that this process will lead to the dominance of U.S. accounting principles.

Other authors noticed that the U.S. accounting principles have not been accepted without resistance at national level, which gives an argument for the adoption of an accounting system different from the U.S. one. Scheid and Standish (1989) explained this resistance with the fact that non-English speaking countries had to abandon their national accounting practices and adopt Anglo-American accounting norms. Baker (1986) observed that for many countries the adoption of an international standard is politically more correct than the complete introduction of the whole body of U.S. or U.K. accounting principles. Le Fèvre (1990) believed that in the process of accounting harmonization a servile attitude towards other countries would not be acceptable, since European countries should be viewed as separate social units. 
However, many scholars noticed that the accounting harmonization could be viewed as an invasive process over national accounting standards. For instance, Hoaru (1995) suggested that the French accounting system was more homogenized before the IASC's regulatory intervention. Nobes (1995) also proposed that some countries, like France, had adopted the IASC regulation, because the globalization of financial markets stimulated that process. However, he rejected the explanations of other authors (e.g. Tang, 1994) that the accounting harmonization is a result of a pressure coming from some organizations, such as IASB, or countries, like the U.S.

\subsubsection{Accounting harmonization in a competitive environment}

Conflicting views about the harmonization process in the competitive international environment have been expressed as well. No consensus has been reached whether global standards setting has to rely on competitive forces or not. Flower (1994) looked from the view of a manager deciding in which country to establish his business. He underlined that reporting differences within the European Common Market might lead to a comparative competitive advantage for a country with less transparent disclosure policy. As national governments compete to attract more companies within their jurisdictions, for job market or tax purposes, they will create a tendency towards lower reporting requirements. He believed that the process of accounting harmonization will resolve this problem and will introduce high-quality standards within the EU.

The proponents of competing regulatory jurisdictions, i.e. different accounting standards, however, underlined that throughout the process of trial-and-error the most efficient and high-quality rules will survive. Their primary belief is that there has been always an implicit demand by managers of public corporations for high-quality accounting standards, since financial market value public disclosure and discriminate between reliable and non-reliable information (Dye and Sunder, 2001). 


\section{PRINCIPLE DIFFERENCES BETWEEN IFRS AND PGC}

There are regulatory differences between the former and newly introduced accounting rules for Spanish companies, which can lead to significant material differences in their income statements. The main differences refer basically to the application of the fair value, cost capitalization and accounting for goodwill. A short description for each of them follows.

\subsection{Fair value ${ }^{1}$ application}

Under IAS 16, IAS 38 and IAS 40 tangible and intangible assets should initially be recorded in the balance sheet at cost, i.e. the acquisition price less costs directly attributable to their operation cycle. The international accounting standards on property, plant and equipment (IAS 16), intangible assets (IAS 38) and investment property (IAS 40) permit two alternative recognition methods: cost model and revaluation model. In the first case, the asset is carried at cost less accumulated depreciation and impairment. The revaluation model allows the asset to be carried at a revalued amount, which is its fair value at the date of revaluation. The Spanish accounting principles, in contrast, generally permit only the cost recognition model, while asset revaluation is possible only if it has been legally provided in special cases.

The application of the fair value principle to the financial instruments is expected to have a significant impact on the income statements of the Spanish companies, due to

\footnotetext{
${ }^{1}$ Fair value is the amount for which an asset could be exchanged, or a liability settled, between knowledgeable, willing parties in an arm's length transaction (IASB definition).
} 
the fair value model application (including transaction costs, for assets and liabilities not measured at fair value through profit or loss) under IAS 32 and IAS $39^{2}$.

\subsection{Costs capitalization}

It is also expected that the difference in cost capitalization rules between IFRS and PGC will introduce significant material impact on the Profit and Loss Accounts of the Spanish companies. In Spain, as it is in Italy, deferred costs such as research costs, start-up costs, advertising costs related to a new business or product, some goodwill costs and some other costs can be capitalized. For instance the set-up costs under PGC are capitalized over five years. These accounting methods are not acceptable under IFRS (e.g. IAS 38).

\subsection{Accounting for goodwill}

Under IFRS 3, goodwill is no longer deemed to have a finite life and is therefore not amortized. This is an important difference in comparison with PGC, where it was allowed to amortize the goodwill. One of the most significant changes introduced by IFRS 3 is the fact that intangible assets other than goodwill that are recognized on the balance sheet will either be amortized over their useful life or, if appropriate, assigned indefinite lives. Assets with an indefinite life will not be amortized, but will have to undergo an annual impairment test. In the event that it is impaired, an immediate charge will be taken to the income statement. Thus, IFRS 3 introduced a test for value deterioration of the intangible assets and poor-performing acquisitions will be highlighted through such a charge sooner rather than later.

\footnotetext{
2 There are some exceptions, such as loans and receivables, held-to-maturity investments, and nonderivative financial liabilities should be measured at amortised cost using the effective interest method.
} 


\subsection{Other significant differences}

There are also other significant differences, which IFRS adoption introduces in the consolidated statements of listed Spanish companies. Some of them are as follows:

- Non-realized gains related to exchange rates differences must be incorporated in the income statement.

- The deferred income tax under IFRS is calculated not from the income statement but the Balance Sheet.

- IFRS calculates the discount rate of post employment payments using market returns of bonds of companies with good ratings.

- Associated companies are included in consolidated accounts in accordance with the equity method. When the one group holds, directly or indirectly, at least 20 percent of the voting rights and/or it influences significantly another company, then it should account for that company as an associated company. The Group operating profit then includes the group's share of the associate's earnings and the Group tax expenses include the associate's taxes as well. Under PGC the equity method is used when the holding amounts to 3 percent or higher.

\section{STUDY METHODOLOGY AND SAMPLE SELECTION PROCEDURE}

The objective of this study is to examine the preliminary impact of the IFRS introduction in Spain on income statement. There are four IBEX indexes, namely IBEX Small Cap, IBEX Medium Cap, IBEX New Market and IBEX 35. Each of the indices tracks the performance of a specific "basket" of stocks considered to represent a particular market 
or sector of the Spanish stock market or the economy. The index which measures market trends for Spanish companies is IBEX 35. It is the index, which finance researchers and market analysts refer to when comparing stock market performance across countries.

To account for national trends after the adoption of IFRS in Spain, IBEX 35 has been chosen for this study. IBEX 35 is composed of companies operating in different business segments, among them financial sector. For the purpose of this study, as has been done in numerous empirical studies before, banks and insurance companies have been excluded due to their peculiarity. Additional changes in the sample composition were also made. One of the IBEX-35 companies, namely Arcelor, started IFRS application from the beginning of 2002. As it should not restate its financial results, the company has been excluded from the study. Table 1 provides more details about the sample selection procedure.

\section{TABLE 1 ABOUT HERE}

In accordance with the newly introduced accounting standards in Spain, the companies have published interim results under IFRS. Under IAS 34 the same accounting policies should be applied for interim reporting as are applied in the enterprise's annual financial statements, except for accounting policy changes made after the date of the most recent annual financial statements that are to be reflected in the next annual financial statements. A key provision of IAS 34 is that an enterprise should use the same accounting policy throughout a single financial year. If a decision is made to change a policy mid-year, the change is implemented retrospectively, and previously reported interim data is restated. In addition, financial results for 2005 have to be compared to the previous year's results, as followed under the new international accounting principles. When a company applies for a first time IFRS, it has to make 
public its financial results as if it had been implementing these rules in past financial years.

These reporting requirements made possible the current study. The financial results under PGC and IFRS have been obtained from the interim reports of the IBEX-35 companies. The interim financial performance under both regulatory regimes has been accessed on the corporate websites, together with the reconciliations as provided by the sampled companies. The main focus was on the net profit results for year 2004 . The reconciliation between PGC and IFRS provided the difference due to different recognition and reporting requirements. Table 2 presents the raw data observations.

TABLE 2 ABOUT HERE

\section{RESULTS}

The study shows that there is a large variability in the reported difference in net profit results under PGC and IFRS. The mean value change for the total sample was $-3,9 \%$ (minimum value: $-115 \%$, maximum value: $30 \%$ ). The variation within the sample was very large, i.e. $24,5 \%$, which is most likely due to industry-specific recognition and measurement reporting standards and/or a company with a very large percentage change in comparison to the others, in this case, Cintra with $-115 \%$. The small number of companies does not allow to perform statistical test by industry group. However, in order to check if an outlier (i.e. Cintra) does not determine the results, the IFRS adoption differences have been estimated within a sample, which excludes this extreme observation. Table 3 presents for this reduced sample.

\section{TABLE 3 ABOUT HERE}

The statistical results show that the preliminary effect of the IFRS introduction does not seem to be significant for the net profit performance of the companies in IBEX 35 . 
Once extreme observations have been considered, in this case Cintra, a significant reduction in the standard deviation has been observed. This fact reveals that most likely the variation in the differences coming from IFRS implementation will depend on individual companies composing the index, rather than on a particular trend, since it has not be observed.

Non-parametric statistical methods are appropriate for small samples, since they account for extreme observations. Wilcoxon's test estimates the median of the differences in matched pairs. The null hypothesis is that the median of the differences is zero; no further assumptions about the distributions are made. If there is no significant difference caused by IFRS application, it would be expected that the difference in the sample would be zero. To test if the difference in the reported income statement values is significant, the results are compared with a hypothetical group with zero values. Another test, which estimates the difference in group means, is Johnson's test. Although the test measures the mean difference, its application for small samples is appropriate, as it accounts for extreme observations with adjustments for skewed distributions. Table 4 presents the results of both statistical tests. The null hypothesis is that the impact of IFRS adoption is not significant, i.e. the observed index results would not be statistically different from zero. The results show that we cannot rule out the hypothesis that the mean/median percentage profit change is different from zero. The statistical tests confirm that it does not seem that IFRS adoption changes in a major way the profitability outlook of the companies in IBEX-35.

\section{TABLE 4 ABOUT HERE}

The non-parametric tests, which examine dependence between two groups, are Spearman's and Kendall's rank correlation. These tests may estimate if the change in profit results after IFRS adoption differs across companies of different size and/or profitability rates. Table 5 provides details of both independence tests. The null 
hypothesis is that IFRS implementation changes profit results independently of firm's size or nominal profit value. In other words, the difference would be the same for small and large companies, as it would not differ for more or less profitable business ventures. Both independence tests do not allow us to reject the hypothesis that the difference is independent of firm's size and profit rate. The test suggests that the total assets and profits determine the impact of IFRS adoption on income statements prepared under PGC.

\section{GRAPH 1 ABOUT HERE}

\section{CONCLUSIONS}

This study analyzes the first results of IFRS implementation for the income statement for a sample of Spanish non-financial listed companies. The results confirm that the introduction of international accounting standards may influence the profit results most likely primarily due to the application of fair-value for derivative instruments and new rules for accounting for goodwill. It seems that the new accounting methods under IFRS, especially for costs capitalization, post employment benefits and associated companies, introduce material differences in the income statement of Spanish companies. The empirical test reveals that the adoption of IFRS in Spain has a diverse effect on the net profit, which makes it difficult to predict its impact on the other listed Spanish companies. However, the data analysis shows that the difference that IFRS causes for the consolidated profit does not depend on the profit rate and total assets of the companies. This conclusion implies that the adoption of international accounting standards may influence similarly Spanish companies of different size and profitability. 


\section{REFERENCES}

Archer, G.S., Delvaille, P., \& McLeay, S.J. (1996) "A Statitistical Model of International Accounting Harmonization", Abacus, 32(1): 1-29.

Baccouche, M. (1969) "The Need for International Accountancy", International Journal of Accounting, 2: 97-99.

Baginski, S., Hassell, J. and Kimbrough, M. (2004) "Why Do Managers Explain Their Earnings Forecasts?", Journal of Accounting Research, 42 (1): 1-28.

Baker, R. (1986) "An Assessment Of The Learning Style Preferences Of Accounting Majors". Issues in Accounting Education, 1 (1): 1-12.

Ball, R., Robin, A. and Wu, J. (2003) "Incentives Versus Standards: Properties Of Accounting Income In Four East Asian Countries", Journal of Accounting and Economics, 36 (1-3): 235-270.

Beresford, D. (1990) "Internationalization of Accounting Standards", Accounting Horizons, 4 (1): 99-107.

Cañibano, L. and Mora, A. (2000) "Evaluating the statistical significance of the facto accounting harmonization: a study of European global players", The European Accounting Review, 9 (3): 349-369.

Cecchini, P. (1988) The European Challenge 1992: The Benefits of a Single Market. Wildwood House, Aldershot.

Choi, F. and Levich, R. (1991) "International Accounting Diversity: Does it Affect Market Participants?", Financial Analysts Journal, 47 (4): 73-82. 
Choi, F. and G. Mueller (1984) International Accounting. London: Prentice Hall.

Dye, R. and Sunder, S. (2001) "Why Not Allow FASB And IASB Standards To Compete In the U.S.?", Accounting Horizons, 15 (3): 257-271.

Evans, T. and Taylor, M. (1982) "Bottom-Line Compliance with the IASC: A Comparative Analysis", International Journal of Accounting, 18 (1): 115-128.

Flower, J. (1994) The regulation of financial reporting in the Nordic countries. Stockholm: Fritzes.

GAAP (2001) A survey of national accounting rules benchmarked against International Accounting Standards. Andersen, BDO, Deloitte Touche Tohmatsu, Ernst \& Young, Grant Thornton, KPMG and PricewaterhouseCoopers.

García Benau, M.A. (1995) Armonización de la Información Financiera en Europa. Instituto de Contabilidad y Auditoría de Cuentas. Premio Carlos Cubillo Valverde, ed. 1994. Madrid.

Gray, S. (1980) "The Impact of International Accounting Differences from a Security Analysis Perspective: Some European Evidence", Journal of Accounting Research, 18 (1): 64-76.

Grinyer, J. and Rusell, A. (1992) "National Impediments to International Harmonization: Evidence of Lobbying in the UK", Journal of International Accounting, Auditing and Taxation, 1 (1): 13-31.

Hoarau, C. (1995) "International Accounting Harmonization: American Hegemony or Mutual Recognition with Benchmarks", European Accounting Review, 4 (2): 217-233. Hopwood, A. (1994) "Some Reflections on the harmonization of accounting in within the EU", European Accounting Review, 3 (2): 241-253. 
Hopwood, A., Page, M. and Turley, S. (1990). Understanding Accounting in a Changing Environment. London: Prentice Hall.

Lainez Gadea, J.A., Callao Gastón, S., and Jarne Jarne, J.I. (1996) "International Harmonization of Reporting Required by Stock Markets", The International Journal of Accounting, 31, 405-418.

Le Fevre, A. (1990). Amendments to the 4th Directive. In: The Future of Harmonization of Accounting Standards within the European Communities (104-105): Commission of the European Communities.

Leuz, C. (2003) "IAS versus U.S. GAAP: Information Asymmetry-Bases Evidence from Germany’s New Market", Journal of Accounting Research, 41 (3): 445-472.

Mason, A. (1978) "The Development of International Financial Reporting Standards", International Centre for Research in Accounting: University of Lancaster.

Nobes, C. (1991) Harmonization of Financial Reporting. London: Prentice Hall.

Nobes, C. (1995) "International Accounting Harmonization: A Commentary", European Accounting Review, 4 (2): 249-254.

Pascual, G., León, A. and Zorio, A. (2002) "Measurement of formal harmonization progress: The IASC experience", The International Journal of Accounting, 37, 1-26

Rivera, J. (1990). International Accounting Standards Harmonization and the role of IASC. An Evaluation, presented on the XIII Annual Conference of the European Accounting Association, Budapest.

Scheid, J. and Standish, P. (1989) Accounting Standardization in France and International Accounting Exchanges. London: Prentice Hall. 
Tang, Q. (1994) "Economic Consequences of International Harmonization of Accounting Standards: Theory and its Chinese Application", International Journal of Accounting, 29 (2): 146-160.

Taplin, R. (2003) "Harmony, Statistical Inference with the Herfindahl H Index and C Index", Abacus, 39 (1): 82-94.

Taplin, R., Tower, G. and Hancock, P. (2002) "Disclosure and Compliance of Accounting Policies: Asia-Pacific Evidence", Accounting Forum, 26 (2): 172-190.

Tay, J. and Parker, R. (1990) "Measuring International Harmonization and Standardization", Abacus, 26 (1): 71-88.

Tay, J. and Parker, R. (1992) "Measuring International Harmonization and Standardization: A Reply", Abacus, 28 (2): 211-216.

van der Tas, L. (1988) "Measuring Harmonization of Financial Reporting Practice", Accounting and Business Research, 18 (70): 151-171.

van der Tas, L. (1992) "Measuring International Harmonization and Standardization: A Comment", Abacus, 28 (2): 211-216.

Watts, R. and Zimmerman, J. (1979) "The Demand For And Supply Of Accounting Theories: The Market For Excuses", The Accounting Review, 54 (2): 273-305. 
Table 1: Sample selection

Number of companies in IBEX-35

Less:

Financial companies

(6)

Companies applying IFRS

before 2005

Final sample

28

Table 2: Net profit under PGC and \% change after IFRS adoption

\begin{tabular}{|c|c|c|}
\hline Name of the company & $\begin{array}{l}\text { Net profit under } \\
\text { PGC (€ millions) }\end{array}$ & $\begin{array}{r}\text { \% Change after } \\
\text { IFRS adoption }\end{array}$ \\
\hline Sogecable & -156 & -2 \\
\hline Acerinox & 74 & 4 \\
\hline Indra & 85 & 0 \\
\hline Prisa & 103 & 19 \\
\hline Antena 3 & 105 & 9 \\
\hline TPI & 112 & 2 \\
\hline Red Eléctrica & 132 & -3 \\
\hline Cintra & 144 & -115 \\
\hline Altadis & 146 & 30 \\
\hline Enagas & 158 & 0 \\
\hline Telecinco & 204 & 0 \\
\hline Iberia & 218 & -9 \\
\hline Gamesa & 222 & -21 \\
\hline Acciona & 226 & 3 \\
\hline Metrovacesa & 232 & -6 \\
\hline Sacyr Vallehermoso & 376 & -26 \\
\hline FCC & 388 & -7 \\
\hline Unión Fenosa & 445 & -3 \\
\hline ACS & 460 & -1 \\
\hline Abertis & 467 & -4 \\
\hline Ferrovial & 557 & -5 \\
\hline Inditex & 628 & 2 \\
\hline Gas Natural & 634 & 1 \\
\hline Iberdrola & 1211 & 0 \\
\hline Endesa & 1379 & -9 \\
\hline Telefonica Moviles & 1634 & 4 \\
\hline Repsol YPF & 1950 & 20 \\
\hline Telefonica & 2877 & 8 \\
\hline
\end{tabular}

Source: Corporate interim reports, own calculations

Table 3: Summary statistics 


\begin{tabular}{|l|r|}
\hline Mean & $0,3 \%$ \\
\hline Median & $0 \%$ \\
\hline Standard deviation & $11,3 \%$ \\
\hline Maximum value & $30 \%$ \\
\hline Minimum value & $-26 \%$ \\
\hline
\end{tabular}

Table 4: Median/mean difference

\begin{tabular}{|l|l|l|}
\hline Statistical test & $\begin{array}{l}\text { Wilcoxon's sign test } \\
\text { (median difference) }\end{array}$ & Johnson's adjusted t-test \\
\hline Two-side test & $\begin{array}{l}\operatorname{Pr}(\# \text { positive }>=12 \text { or } \\
\text { \#negative }>=12)=\min (1, \\
\text { 2*Binomial }(\mathrm{n}=23, \mathrm{x}>=12, \\
\mathrm{p}=0.5))=1.0000\end{array}$ & $\begin{array}{l}\mathrm{t}=0.11 \text { with } 26 \mathrm{~d} \text {.f. } \\
\operatorname{Pr}>|\mathrm{t}|=0.9167\end{array}$ \\
\hline $\begin{array}{l}\text { Does not allow to rule out } \\
\text { the possibility that the } \\
\text { median difference is equal } \\
\text { to zero }\end{array}$ & $\begin{array}{l}\text { Does not allow to rule out } \\
\text { the possibility that the } \\
\text { mean difference is equal to } \\
\text { zero }\end{array}$ \\
\hline
\end{tabular}

Table 5: Independence non-parametric tests

\begin{tabular}{|c|c|c|}
\hline & $\begin{array}{l}\text { Independence of profit } \\
\text { change and nominal profit } \\
\text { value }\end{array}$ & $\begin{array}{l}\text { Independence of profit } \\
\text { change and total size }\end{array}$ \\
\hline \multicolumn{3}{|l|}{ Spearman's test } \\
\hline Spearman's rho & -0.0734 & -0.1057 \\
\hline Ho: Independent & Prob $>|t|=$ & Prob $>|t|=$ \\
\hline \multicolumn{3}{|l|}{ Kendall's test } \\
\hline Kendall's tau-a & -0.0370 & -0.0855 \\
\hline Kendall's tau- $b$ & -0.0376 & -0.0868 \\
\hline Kendall's score & -13 & -30 \\
\hline Ho: Independent & $\operatorname{Prob}>|z|=$ & Prob > |z| = \\
\hline Conclusions: & $\begin{array}{l}\text { Does not allow to conclude } \\
\text { that profit change is } \\
\text { dependent of the nominal } \\
\text { profit value }\end{array}$ & $\begin{array}{l}\text { Does not allow to conclude } \\
\text { that profit change is } \\
\text { dependent of the total } \\
\text { assets }\end{array}$ \\
\hline
\end{tabular}

Graph 1: 


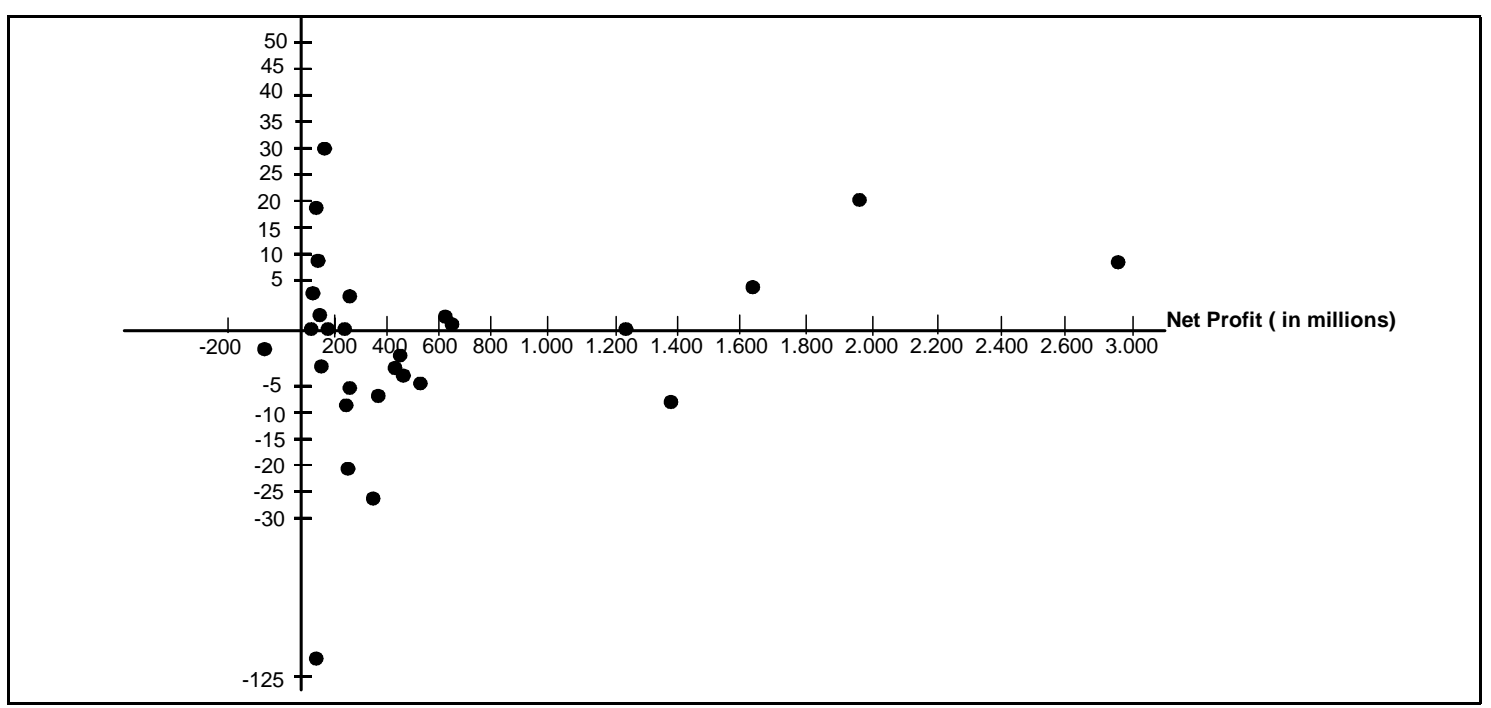

